\title{
Dietzia papillomatosis sp. nov., a novel actinomycete isolated from the skin of an immunocompetent patient with confluent and reticulated papillomatosis
}

\author{
Correspondence \\ Roland J. Koerner \\ Roland.Koerner@ \\ chs.northy.nhs.uk
}

\author{
Amanda L. Jones, ${ }^{1,2}$ Roland J. Koerner, ${ }^{3}$ Sivakumar Natarajan, ${ }^{4}$ \\ John D. Perry ${ }^{2}$ and Michael Goodfellow ${ }^{1}$ \\ ${ }^{1}$ School of Biology, King George Vlth Building, University of Newcastle, \\ Newcastle upon Tyne NE1 7RU, UK \\ ${ }^{2}$ Department of Microbiology, Freeman Hospital, Newcastle upon Tyne NE7 7DN, UK \\ ${ }^{3}$ Department of Microbiology, Sunderland Royal Hospital, Kayll Road, Sunderland SR4 7TP, UK \\ ${ }^{4}$ Department of Dermatology, Sunderland Royal Hospital, Kayll Road, Sunderland SR4 7TP, UK
}

\begin{abstract}
An actinomycete isolated from an immunocompetent patient suffering from confluent and reticulated papillomatosis was characterized using a polyphasic taxonomic approach. The organism had chemotaxonomic and morphological properties that were consistent with its assignment to the genus Dietzia and it formed a distinct phyletic line within the Dietzia 16S rRNA gene tree. It shared a 16S rRNA gene sequence similarity of $98.3 \%$ with its nearest neighbour, the type strain of Dietzia cinnamea, and could be distinguished from the type strains of all Dietzia species using a combination of phenotypic properties. It is apparent from genotypic and phenotypic data that the organism represents a novel species in the genus Dietzia. The name proposed for this taxon is Dietzia papillomatosis; the type strain is $\mathrm{N} 1280^{\top}$ (=DSM $44961^{\top}=\mathrm{NCIMB} 14145^{\top}$ ).
\end{abstract}

The monospecific genus Dietzia was proposed by Rainey et al. (1995) for actinomycetes previously classified as Rhodococcus maris Nesterenko et al. (1982). At the time of writing, the genus Dietzia consists of five species with validly published names: Dietzia kunjamensis (Mayilraj et al., 2006); Dietzia maris (Rainey et al., 1995), the type species; Dietzia cinnamea (Yassin et al., 2006); Dietzia natronolimnaea (Duckworth et al., 1998); and Dietzia psychralcaliphila (Yumoto et al., 2002). The type strains of these species form a distinct $16 \mathrm{~S}$ rRNA gene clade within the evolutionary radiation occupied by mycolic-acid-containing actinomycetes, that is, by organisms classified in the suborder Corynebacterineae (Stackebrandt et al., 1997; Butler et al., 2005; Soddell et al., 2006; Yassin et al., 2006).

D. maris strains have been isolated from the skin and intestinal tract of carp, from soil and from deep-sea sediments in the Pacific Ocean (Nesterenko et al., 1982; Rainey et al., 1995; Takami et al., 1997; Colquhoun et al., 1998), D. cinnamea was isolated from a perianal swab of a patient with a bone marrow transplant (Yassin et al., 2006), D. kunjamensis from a cold desert soil (Mayilraj, et al., 2006), D. natronolimnaea from a moderately saline and

The GenBank/EMBL/DDBJ accession number for the 16S rRNA gene sequence of strain $N 1280^{\top}$ is $A Y 643401$. alkaline East African soda lake (Duckworth et al., 1998) and D. psychralcaliphila was isolated from a drain pool of a fish-egg-processing plant (Yumoto et al., 2002). Species of the genus Dietzia have been reported as potential human pathogens in an immunocompetent patient (Pidoux et al., 2001) and in immunocompromised patients (BemerMelchior et al., 1999; Yassin et al., 2006).

The aim of the present investigation was to determine the taxonomic position of an actinomycete that had been isolated from the skin of an immunocompetent patient with confluent and reticulated papillomatosis and presumptively assigned to the genus Dietzia (Natarajan et al., 2005). The isolate was the subject of a polyphasic taxonomic investigation which showed that it warrants recognition as a novel species of the genus Dietzia.

Strain $\mathrm{N} 1280^{\mathrm{T}}$ was isolated from skin scrapings from a patient suffering from confluent and reticulated papillomatosis, as described by Natarajan et al. (2005). The organism was maintained on glucose-yeast extract agar (GYEA; Gordon \& Mihm, 1962) at room temperature and as glycerol suspensions $(20 \%, \mathrm{v} / \mathrm{v})$ at $-20{ }^{\circ} \mathrm{C}$. Biomass required for chemotaxonomic and $16 \mathrm{~S}$ rRNA gene sequence analyses was obtained by growing the novel strain in shake flasks of glucose-yeast extract (GYE) broth 
for 5 days at $28{ }^{\circ} \mathrm{C}$; cells were checked for purity and harvested by centrifugation. Cells for chemosystematic studies were washed twice in distilled water and freezedried; those for $16 \mathrm{~S}$ rRNA gene sequencing were washed in $\mathrm{NaCl} /$ EDTA buffer (0.1 M EDTA, $0.1 \mathrm{M} \mathrm{NaCl}, \mathrm{pH}$ 8.0) and stored at $-20{ }^{\circ} \mathrm{C}$ until required.

The phylogenetic position of strain $\mathrm{N} 1280^{\mathrm{T}}$ was determined by $16 \mathrm{~S}$ rRNA gene sequence analysis. Isolation of chromosomal DNA, PCR amplification and direct sequencing of the purified products were carried out after Kim et al. (1998). The resultant $16 \mathrm{~S}$ rRNA gene sequence (1437 nt) was aligned manually with corresponding sequences of representatives of the suborder Corynebacterineae, retrieved from the DDBJ/EMBL/GenBank databases, using the pairwise alignment option and 16S rRNA secondary structural information held in the program PHYDIT (available at http://plaza.snu.ac.kr/ jchun/phydit/). Phylogenetic trees were inferred using the least-squares (Fitch \& Margoliash, 1967), neighbour-joining (Saitou \& Nei, 1987), maximum-likelihood (Felsenstein, 1981) and maximum-parsimony (Kluge \& Farris, 1969) tree-making algorithms from the PHYLIP suite of programs (Felsenstein, 1993); evolutionary distance matrices were prepared after Jukes \& Cantor (1969). The topologies of the resultant unrooted trees were evaluated in a bootstrap analysis (Felsenstein, 1985) based on 1000 resamplings of the neighbour-joining dataset using the CONSENSE and SEQBOOT options from the PHYLIP package.

It is apparent from Fig. 1 that strain $\mathrm{N} 1280^{\mathrm{T}}$ belongs to the Dietzia $16 \mathrm{~S}$ rRNA gene clade, an association supported by the three tree-making algorithms and by a $100 \%$ bootstrap value in the neighbour-joining analysis. The novel strain was most closely related to the type strain of $D$. cinnamea: the two organisms had a 16S rRNA gene sequence similarity of $98.3 \%$, a value that corresponds to 24 nucleotide differences at 1437 locations. Lower similarity values were recorded for the type strains of D. kunjamensis (95.6\%), D. maris (96.4\%), D. natronolimnaea (95.5\%) and D. psychralcaliphila (94.6\%). DNA-DNA relatedness studies were not carried out between these strains as the type strains of D. kunjamensis and D. maris share a high 16S rRNA gene sequence similarity value, but have a DNADNA relatedness value of only $59.2 \%$ (Mayilraj et al., 2006), a figure well below the $70 \%$ guideline recommended for the delineation of bacterial species (Wayne et al., 1987).

Strain $\mathrm{N} 1280^{\mathrm{T}}$ was examined for key chemotaxonomic markers to establish if it had chemical properties that were characteristic of Dietzia strains. Standard procedures were used to determine the diagnostic isomers of diaminopimelic acid ( $\mathrm{A}_{2} \mathrm{pm}$; Staneck \& Roberts, 1974), fatty acids (Sutcliffe, 2000), isoprenoid quinones (Collins, 1994), muramic acid type (Uchida et al., 1999), mycolic acids (Hamid et al., 1993), polar lipids (Minnikin et al., 1984) and wholeorganism sugars (Hasegawa et al., 1983). The organism contained meso- $\mathrm{A}_{2} \mathrm{pm}$, arabinose and galactose in wholeorganism hydrolysates (wall chemotype IV sensu Lechevalier \& Lechevalier, 1970), $\mathrm{N}$-acetyl muramic acid, dihydrogenated menaquinones with eight isoprene units [MK- $\left.8\left(\mathrm{H}_{2}\right)\right]$ as the predominant isoprenologue and a minor amount of MK-7 $\left(\mathrm{H}_{2}\right)$, straight-chain saturated, unsaturated and tuberculostearic acids (fatty acid type $1 \mathrm{~b}$ sensu Kroppenstedt, 1985) as major fatty acids, phosphatidylethanolamine, phosphatidylglycerol and diphosphatidylglycerol as major polar lipids, and mycolic acids that co-migrated with those from D. maris DSM $43672^{\mathrm{T}}$. This chemotaxonomic profile is consistent with classification of the novel strain in the genus Dietzia (Goodfellow \& Maldonado, 2006).

The novel strain and $D$. cinnamea DSM $44904^{\mathrm{T}}, D$. kunjamensis DSM 44907 ${ }^{\mathrm{T}}$, D. maris DSM 43672 $2^{\mathrm{T}}, D$.

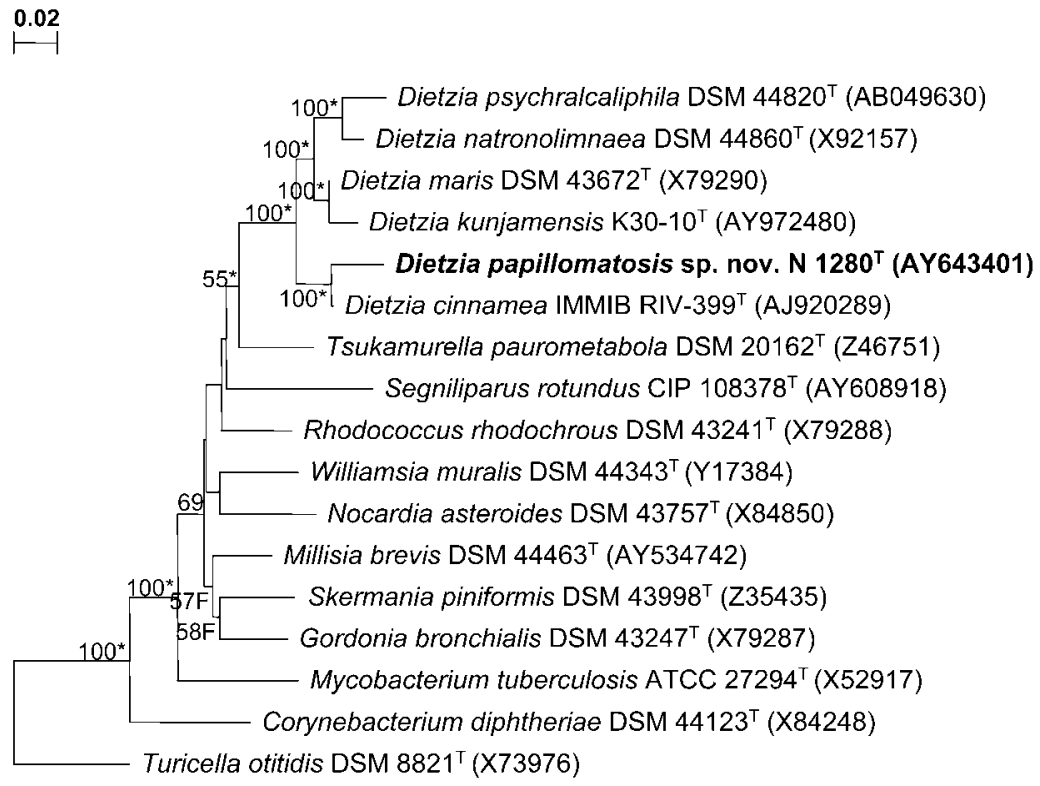

Fig. 1. Neighbour-joining tree (Saitou \& Nei, 1987) based on a nearly complete $16 \mathrm{~S}$ rRNA gene sequence of strain $\mathrm{N} 1280^{\top}$ showing its position in the Dietzia clade. Asterisks indicate branches of the tree that were also found using the least-squares (Fitch \& Margoliash, 1967), maximum-likelihood (Felsenstein, 1981) and maximum-parsimony (Kluge \& Farris, 1969) tree-making algorithms. $\mathrm{F}$ indicates branches that were also recovered using the leastsquares method. The numbers at the nodes indicate the levels of bootstrap support based on a neighbour-joining analysis of 1000 resampled datasets; only values above $50 \%$ are given. Bar, 0.02 substitutions per nucleotide position. 
natronolimnaea DSM $44806^{\mathrm{T}}$ and D. psychralcaliphila DSM $44820^{\mathrm{T}}$ were examined for a range of degradative properties using well-established procedures (Goodfellow, 1971; Isik et al., 1999). Aesculin and arbutin hydrolysis were examined following Williams et al. (1983), allantoin hydrolysis was according to Gordon (1967), nitrate reduction was following Gordon \& Mihm (1962) and urease production was as described by Rustigan \& Stuart (1941). The oxidase reaction was performed on filter paper moistened with a $1 \%(\mathrm{w} / \mathrm{v})$ aqueous solution of $N, N, N^{\prime}, N^{\prime}$-tetramethyl-p-phenylenediamine and catalase activity was demonstrated using $3 \%(\mathrm{v} / \mathrm{v})$ hydrogen peroxide. Acid production from carbohydrates was carried out using media and methods described by Gordon et al. (1974) and utilization of sole carbon and sole carbon/ nitrogen sources were determined after Stevenson (1967) and Tsukamura (1966), respectively. Tolerance to $\mathrm{pH}$, temperature and sodium chloride were established using GYEA plates that were incubated for up to 14 days. Resistance to lysozyme was determined after Gordon et al. (1974). It is evident from Table 1 that although the Dietzia strains have many properties in common, they can be distinguished from each other using a combination of phenotypic features.

The antibiotic sensitivity profile of strain $\mathrm{N} 1280^{\mathrm{T}}$ was established by placing discs impregnated with antibiotics (Oxoid), six per plate, over GYEA plates and incubating them for 2 days at $30{ }^{\circ} \mathrm{C}$ prior to recording zones of inhibition around the discs. The colonial properties of the strain were examined on a modified Bennett's agar plate (Jones, 1949) after incubation for 5 days at $30{ }^{\circ} \mathrm{C}$. Smears

Table 1. Phenotypic properties that distinguish strain $\mathrm{N} 1280^{\top}$ and the type strains of Dietzia species

Strains: $1, \mathrm{~N} 1280^{\mathrm{T}} ; 2$, D. cinnamea DSM $44904^{\mathrm{T}} ; 3$, D. kunjamensis DSM $44907^{\mathrm{T}} ; 4$, D. maris DSM 43672 ${ }^{\mathrm{T}} ; 5$, D. natronolimnaea DSM $44860^{\mathrm{T}} ; 6$, D. psychralcaliphila DSM $44820^{\mathrm{T}}$. All data are from the present study. All strains hydrolysed allantoin, arbutin and urea, were catalase-positive, reduced nitrate, were resistant to lysozyme, degraded cellulose, starch, Tweens 40 and 60 , and grew at $37{ }^{\circ} \mathrm{C}$ and $\mathrm{pH} 7$ and 10 . Adonitol, L-arabinose, arbutin, butane-1,3-diol, butane-1,4-diol, butane-1-ol, butane-2,3-diol, D-cellobiose, dextrin, ethanol, meso-erythritol, D-fructose, D- and L-fucose, D-galactose, D-gentiobiose, D-glucose, glycerol, myo-inositol, D-lactose, maltose, D-mannitol, D-mannose, D-melezitose, D-melibiose, propane-1,2diol, propane-1,3-diol, D-raffinose, D-ribose, D-salicin, D-sorbitol, sucrose, D-tagatose, trehalose, turanose, D-xylose and D-xylitol were used as sole carbon sources by all strains [all at $1.0 \%(\mathrm{w} / \mathrm{v})$ or $1.0 \%(\mathrm{v} / \mathrm{v})$ ]. Acetamide, L-alanine, L-asparagine, L-aspartic acid, L-glutamic acid, L-glycine, Lhistidine, L-leucine, L-isoleucine, DL-norleucine, L-norvaline, L-ornithine, DL-phenylalanine, L-proline, L-serine, L-thymidine, L-valine and urea were used as sole carbon and nitrogen sources. All strains were negative for aesculin hydrolysis, oxidase activity and degradation of casein, DNA, gelatin, hypoxanthine, pectin, RNA, xanthine and xylan. None of the strains utilized sodium adipate, sodium gluconate, sodium malonate, sodium oleate, sodium oxalate, sodium suberate or sodium succinate as sole carbon sources (all at $0.1 \%$, w/v) or grew at pH 5.0. +, Positive; -, negative; w, weakly positive.

\begin{tabular}{|c|c|c|c|c|c|c|}
\hline Characteristic & 1 & 2 & 3 & 4 & 5 & 6 \\
\hline Colony colour & Orange & Orange & Coral red & Orange & Coral red & Coral red \\
\hline Nitrite reduction & - & - & - & - & + & - \\
\hline \multicolumn{7}{|l|}{ Degradation of: } \\
\hline Chitin & + & - & + & + & + & + \\
\hline Elastin & - & - & + & + & + & + \\
\hline L-Tyrosine & + & - & - & + & - & + \\
\hline Tributyrin & - & - & - & + & + & + \\
\hline Uric acid & - & - & + & - & - & - \\
\hline \multicolumn{7}{|c|}{ Acid production (aerobically) from: } \\
\hline D-Fructose & + & + & - & + & + & + \\
\hline D-Glucose & - & + & + & - & + & + \\
\hline D-Mannose & - & + & - & - & + & - \\
\hline D-Raffinose & - & - & - & $\mathrm{w}$ & $\mathrm{w}$ & $\mathrm{w}$ \\
\hline Sucrose & - & + & + & + & + & + \\
\hline \multicolumn{7}{|c|}{ Utilization as sole carbon and nitrogen sources: } \\
\hline L-Arginine & - & + & + & - & - & + \\
\hline L-Cysteine & + & + & + & + & + & - \\
\hline \multicolumn{7}{|l|}{ Growth at: } \\
\hline $5{ }^{\circ} \mathrm{C}$ & - & - & - & - & - & + \\
\hline $10{ }^{\circ} \mathrm{C}$ & - & + & + & + & + & + \\
\hline $45{ }^{\circ} \mathrm{C}$ & - & - & + & + & + & + \\
\hline \multicolumn{7}{|c|}{ Growth in the presence of: } \\
\hline $7 \%(\mathrm{w} / \mathrm{v}) \mathrm{NaCl}$ & + & + & + & + & + & - \\
\hline $8 \%(\mathrm{w} / \mathrm{v}) \mathrm{NaCl}$ & + & + & - & - & + & - \\
\hline
\end{tabular}


from this plate were prepared and Gram stained (Hucker's modification; Society for American Bacteriologists, 1957); they were also stained using a modification of the ZiehlNeelson method (Gordon, 1967) to determine acidalcohol-fastness. The isolate produced orange-pigmented colonies and was Gram-positive and non-acid-alcohol-fast.

The cells required for determination of cellular morphology of the organism were grown in shake flasks of GYE broth for 24,48 and $72 \mathrm{~h}$ at $28{ }^{\circ} \mathrm{C}$; cells were checked for purity at each of these times and harvested by centrifugation. The resultant preparations were fixed in $2 \%$ glutaraldehyde in Sorenson's phosphate buffer for $4 \mathrm{~h}$ proceeded by washing three times with $1 \times$ phosphate buffer solution. Cell suspensions were inoculated on to separate coverslips coated with $0.025 \%$ poly-L-lysine, dehydrated in a graduated ethanol series $(25-100 \%$, v/v), critical-point-dried in $\mathrm{CO}_{2}$, fixed on a specimen mount with Acheson Silver DAG, gold coated and examined using a Cambridge Stereoscan S40 scanning electron microscope. Strain $\mathrm{N} 1280^{\mathrm{T}}$ exhibited a rod-coccus life cycle: younger cultures exhibited snapping division and V-forms (1.0$1.4 \times 0.2-0.4 \mu \mathrm{m}$ in size).

It can be concluded from the genotypic and phenotypic data that strain $\mathrm{N} 1280^{\mathrm{T}}$ can be readily distinguished from the recognized Dietzia species and hence should be classified as a representative of a novel species in the genus Dietzia. The name proposed for this taxon is Dietzia papillomatosis sp. nov.

\section{Description of Dietzia papillomatosis sp. nov.}

Dietzia papillomatosis (pa.pil.lo.ma.to'sis. N.L. gen. n. papillomatosis of papillomatosis).

Aerobic, Gram-positive, non-motile, non-spore-forming, non-acid-alcohol-fast actinomycete that shows snapping division and V-forms and a rod-coccus life cycle. Circular, convex, shiny, orange-pigmented colonies are formed on modified Bennett's agar after growth for 5 days at $30{ }^{\circ} \mathrm{C}$. Neither aerial hyphae nor diffusible pigments are formed. Degrades Tweens 20 and 80, but not adenine. Utilizes isoamyl alcohol as a sole carbon source for energy and growth (at $1 \%, v / v)$. Similarly, fumaric acid, $m$-hydroxybenzoic acid, DL- $\beta$-hydroxybutyric acid, sodium acetate, sodium benzoate, sodium n-butyrate, sodium propionate, sodium pyruvate and sodium DL-malate are used as sole carbon sources, but not 3,3-dimethylglutaric acid, sodium azelate, sodium citrate, sodium pimelate or sodium sebacate (all at $0.1 \%, w / v)$. Growth occurs in the presence of filter paper discs soaked in cephalexin $\left(30 \mu \mathrm{g} \mathrm{ml}^{-1}\right)$, clindamycin hydrochloride $\left(2 \mu \mathrm{g} \mathrm{ml} \mathrm{m}^{-1}\right)$, colistin $(25 \mu \mathrm{g}$ $\left.\mathrm{ml}^{-1}\right)$, erythromycin $\left(5 \mu \mathrm{g} \mathrm{ml}{ }^{-1}\right)$, nalidixic acid $(30 \mu \mathrm{g}$ $\left.\mathrm{ml}^{-1}\right)$, novobiocin $\left(5 \mu \mathrm{g} \mathrm{ml}{ }^{-1}\right)$ and tetracycline hydrochloride $\left(10 \mu \mathrm{g} \mathrm{ml}^{-1}\right)$, but not in the presence of bacitracin $(10 \mathrm{U})$, ciprofloxacin $\left(5 \mu \mathrm{g} \mathrm{ml}{ }^{-1}\right)$, cotrimoxazole $(25 \mu \mathrm{g}$ $\left.\mathrm{ml}^{-1}\right)$, fusidic acid $\left(10 \mu \mathrm{g} \mathrm{ml}^{-1}\right)$ or penicillin $\left(1 \mu \mathrm{g} \mathrm{ml}^{-1}\right)$. Additional phenotypic properties are shown in Table 1. The cell-wall amino acid is meso-diaminopimelic acid and the major cell-wall sugars are arabinose and galactose. The glycan moiety of the cell wall contains $\mathrm{N}$-acetyl residues ( $N$-acetylmuramic acid). Whole-cell fatty acids consist of predominantly straight-chain saturated and unsaturated components, namely pentadecanoic acid (C15:0; 5.4\%), hexadecanoic acid $(\mathrm{C} 16: 0 ; 21.1 \%)$, monounsaturated hexadecenoic acid (C16:1; 3.0\%), septadecanoic acid $(\mathrm{C} 17: 0 ; 6.1 \%)$, monounsaturated septadecenoic acid (C17: $1 ; 2.7 \%)$, monounsaturated octadecenoic acid (C18: 1; $9.0 \%)$, tuberculostearic acid $(22.1 \%)$, nonadecanoic acid (C19:0; $2.6 \%)$ and unidentified peaks with the retention times of 19.99 (10.6\%), $21.61(5.6 \%)$ and 21.88 (5.7\%). The polar lipid profile consists of phosphatidylethanolamine, phosphatidylglycerol and diphosphatidylglycerol. MK-8( $\left.\mathrm{H}_{2}\right)$ is the major menaquinone and MK$7\left(\mathrm{H}_{2}\right)$ is the minor one.

The type strain, $\mathrm{N} 1280^{\mathrm{T}} \quad\left(=\mathrm{DSM} \quad 44961^{\mathrm{T}}=\mathrm{NCIMB}\right.$ $\left.14145^{\mathrm{T}}\right)$, was isolated from the skin of an immunocompetent patient with confluent and reticulated papillomatosis.

\section{Acknowledgements}

Amanda Jones is grateful to the Freeman Hospital, Newcastle upon Tyne, and to the School of Biology, University of Newcastle, Newcastle upon Tyne, for financial support. The authors are indebted to Dr Iain Sutcliffe (University of Northumbria, Newcastle upon Tyne) for help with the fatty acid analysis of the type strain of Dietzia papillomatosis, the Electron Microscopy Research Services for their assistance with the scanning electron microscopy and to Dr Jean Euzéby and Professor Dr Hans Trüper for their help with naming the new taxon.

\section{References}

Bemer-Melchior, P., Haloun, A., Riezel, P. \& Drugeon, H. (1999). Bacteremia due to Dietzia maris in an immunocompromised patient. Clin Infect Dis 29, 1338-1340.

Butler, W. R., Floyd, M. M., Brown, J., Toney, S. R., Daneshvar, M. I., Cooksey, R. C., Carr, J., Steigerwalt, A. G. \& Charles, N. (2005). Novel mycolic acid-containing bacteria in the family Segniliparaceae gen. nov., including the genus Segniliparus gen. nov., with descriptions of Segniliparus rotundus sp. nov., and Segniliparus rugosus sp. nov. Int J Syst Evol Microbiol 55, 1615-1624.

Collins, M. D. (1994). Isoprenoid quinones. In Chemical Methods in Prokaryotic Systematics, pp. 265-309. Edited by M. Goodfellow \& A. G. O’Donnell. Chichester, UK: John Wiley.

Colquhoun, J. A., Mexson, J., Goodfellow, M., Ward, A. C., Horikoshi, K. \& Bull, A. T. (1998). Novel rhodococci and other mycolate actinomycetes from the deep sea. Antonie van Leeuwenhoek 74, 27-40.

Duckworth, A. W., Grant, S., Grant, W. D., Jones, B. E. \& Meijer, D. (1998). Dietzia natronolimnaea sp. nov., a new member of the genus Dietzia isolated from an East African soda lake. Extremophiles 2, 359-366.

Felsenstein, J. (1981). Evolutionary trees from DNA sequences: a maximum likelihood approach. J Mol Evol 17, 368-376.

Felsenstein, J. (1985). Confidence limits on phylogenies: an approach using the bootstrap. Evolution 39, 783-791.

Felsenstein, J. (1993). PHYLIP (phylogeny inference package) version 3.5c. Distributed by the author. Department of Genome Sciences, University of Washington, Seattle, USA. 
Fitch, W. M. \& Margoliash, E. (1967). Construction of phylogenetic trees: a method based on mutation distances as estimated from cytochrome $c$ sequences is of general applicability. Science 155, 279-284.

Goodfellow, M. (1971). Numerical taxonomy of some nocardioform bacteria. J Gen Microbiol 69, 33-80.

Goodfellow, M. \& Maldonado, L. A. (2006). The families Dietziaceae, Gordoniaceae, Nocardiaceae and Tsukamurellaceae. In The Prokaryotes, 3rd edn., Vol. 3, Archaea, Bacteria, Firmicutes, Actinomycetes, pp. 843888. Edited by Dworkin, M., Falkow, S., Rosenberg, E., Schleifer, K. H. \& Stackebrandt, E. New York: Springer.

Gordon, R. E. (1967). The taxonomy of soil bacteria. In The Ecology of Soil Bacteria, pp. 293-321. Edited by T. R. G. Gray \& D. Parkinson. Liverpool: Liverpool University Press.

Gordon, R. E. \& Mihm, J. M. (1962). Identification of Nocardia caviae (Erikson) nov. comb. Ann N Y Acad Sci 98, 628-636.

Gordon, R. E., Barnett, D. A., Handerhan, J. E. \& Pang, C. H.-N. (1974). Nocardia coeliaca, Nocardia autotrophica, and the nocardin strain. Int J Syst Bacteriol 24, 54-63.

Hamid, M. E., Minnikin, D. E., Goodfellow, M. \& Ridell, M. (1993). Thin-layer chromatographic analysis of glycolipids and mycolic acids from Mycobacterium farcinogenes, Mycobacterium senegalense and related taxa. Zentralbl Bakteriol 279, 354-367.

Hasegawa, T., Takizawa, M. \& Tanida, S. (1983). A rapid analysis for chemical grouping of aerobic actinomycetes. J Gen Appl Microbiol 329, 1319-1322.

Isik, K., Chun, J., Hah, Y. C. \& Goodfellow, M. (1999). Nocardia salmonicida nom. rev., a fish pathogen. Int J Syst Bacteriol 49, 833-837.

Jones, K. L. (1949). Fresh isolates of actinomycetes in which the presence of sporogeneous aerial mycelia is a fluctuating characteristic. $J$ Bacteriol 57, 141-145.

Jukes, T. H. \& Cantor, C. R. (1969). Evolution of protein molecules. In Mammalian Protein Metabolism, pp. 21-132. Edited by H. N. Munro. New York: Academic Press.

Kim, S. B., Falconer, C., Williams, E. \& Goodfellow, M. (1998). Streptomyces thermocarboxydovorans sp. nov. and Streptomyces thermocarboxydus sp. nov., two moderately thermophilic carboxydotrophic species from soil. Int J Syst Bacteriol 48, 59-68.

Kluge, A. G. \& Farris, F. S. (1969). Quantitative phyletics and the evolution of anurans. Syst Zool 18, 1-32.

Kroppenstedt, R. M. (1985). Fatty acid and menaquinone analysis of actinomycetes and related organisms. In Chemical Methods in Bacterial Systematics (Society for Applied Bacteriology Technical Series vol. 20), pp. 173-199. Edited by M. Goodfellow \& D. E. Minnikin. New York: Academic Press.

Lechevalier, M. P. \& Lechevalier, H. A. (1970). Chemical composition as a criterion in the classification of aerobic actinomycetes. Int J Syst Bacteriol 20, 435-443.

Mayilraj, S., Suresh, S., Kroppenstedt, R. M. \& Saini, H. S. (2006). Dietzia kunjamensis sp. nov., isolated from the Indian Himalayas. Int $J$ Syst Evol Microbiol 56, 1667-1671.

Minnikin, D. E., O'Donnell, A. G., Goodfellow, M., Alderson, G., Athalye, M., Schaal, A. \& Parlett, J. H. (1984). An integrated procedure for the extraction of isoprenoid quinones and polar lipids. J Microbiol Methods 2, 233-241.

Natarajan, S., Milne, D., Jones, A. L., Goodfellow, M., Perry, J. \& Koerner, R. J. (2005). The etiological agent of confluent and reticulated papillomatosis? Br J Dermatol 153, 825-827.
Nesterenko, O. A., Nogina, T. M., Kasumova, S. A., Kvasnikov, E. I. \& Batrakov, S. G. (1982). Rhodococcus luteus nom. nov. and Rhodococcus maris nom. nov. Int J Syst Bacteriol 32, 1-14.

Pidoux, O., Argenson, J.-N., Jacomo, V. \& Drancourt, M. (2001). Molecular identification of a Dietzia maris hip prosthesis infection isolate. J Clin Microbiol 39, 2634-2636.

Rainey, F. A., Klatte, S., Kroppenstedt, R. M. \& Stackebrandt, E. (1995). Dietzia, a new genus including Dietzia maris comb. nov., formerly Rhodococcus maris. Int J Syst Bacteriol 45, 32-36.

Rustigan, R. \& Stuart, C. A. (1941). Decomposition of urea by Proteus. Proc Soc Exp Biol Med 47, 108-112.

Saitou, N. \& Nei, M. (1987). The neighbor-joining method: a new method for reconstructing phylogenetic trees. Mol Biol Evol 4, 406-425.

Society for American Bacteriologists (1957). Manual for Microbiological Methods. New York: McGraw-Hill.

Soddell, J. A., Stainsby, F. M., Eales, K. L., Kroppenstedt, R. M., Seviour, R. J. \& Goodfellow, M. (2006). Millisia brevis gen. nov., sp. nov., an actinomycete isolated from activated sludge foam. Int J Syst Evol Microbiol 56, 739-744.

Stackebrandt, E., Rainey, F. A. \& Ward-Rainey, N. L. (1997). Proposal for a new hierarchic classification system, Actinobacteria classis nov. Int J Syst Bacteriol 47, 479-491.

Staneck, J. L. \& Roberts, G. D. (1974). Simplified approach to the identification of aerobic actinomycetes by thin-layer chromatography. Appl Microbiol 28, 226-231.

Stevenson, I. L. (1967). Utilization of aromatic hydrocarbons by Arthrobacter spp. Can J Microbiol 13, 205-211.

Sutcliffe, I. C. (2000). Characterisation of a lipomannan lipoglycan from the mycolic acid containing actinomycete Dietzia maris. Antonie van Leeuwenhoek 78, 195-201.

Takami, H., Inoue, A., Fuji, F. \& Horikoshi, K. (1997). Microbial flora in the deepest sea mud of the Mariana Trench. FEMS Microbiol Lett 152, 279-285.

Tsukamura, M. (1966). Adansonian classification of mycobacteria. J Gen Microbiol 45, 253-273.

Uchida, K., Kudo, T., Suzuki, K. \& Nakase, T. (1999). A new rapid method of glycolate test by diethyl ether extraction, which is applicable to a small amount of bacterial cells of less than one milligram. J Gen Appl Microbiol 45, 49-56.

Wayne, L. G., Brenner, D. J., Colwell, R. R., Grimont, P. A. D., Kandler, O., Krichevsky, M. I., Moore, L. H., Moore, W. E. C., Murray, R. G. E. \& other authors (1987). International Committee on Systematic Bacteriology. Report of the ad hoc committee on reconciliation of approaches to bacterial systematics. Int J Syst Bacteriol 37, 463-464.

Williams, S. T., Goodfellow, M., Alderson, G., Wellington, E. M. H., Sneath, P. H. A. \& Sackin, M. J. (1983). Numerical classification of Streptomyces and related genera. J Gen Microbiol 129, 1743-1813.

Yassin, A. F., Hupfer, H. \& Schaal, K. P. (2006). Dietzia cinnamea sp. nov., a novel species of the genus Dietzia isolated from a perianal swab of a patient with a bone marrow transplant. Int J Syst Evol Microbiol 56, 641-645.

Yumoto, I., Nakamura, A., Iwata, H., Kojima, K., Kusumoto, K., Nodosaka, Y. \& Matsuyama, H. (2002). Dietzia psychralcaliphila sp. nov., a novel facultatively psychrophilic alkaliphile that grows on hydrocarbons. Int J Syst Evol Microbiol 52, 85-90. 